\title{
Implementation of Transforaminal Endoscopic Lumbar Sequestrectomy in a German University Hospital Setting: A Long and Rocky Road
}

\author{
Michael Bender ${ }^{1}$ Carolin Gramsch ${ }^{1} \quad$ Lukas Herrmann $^{1}$ Seong Woong Kim ${ }^{1}$ Eberhard Uhl ${ }^{1}$ \\ Karsten Schöller ${ }^{1}$ \\ ${ }^{1}$ Department of Neurosurgery, Universitatsklinikum Giessen und \\ Marburg, Giessen, Germany \\ 2 Department of Neuroradiology, Justus-Liebig-University Giessen, \\ Giessen, Germany \\ Address for correspondence Dr. Michael Bender, Department of \\ Neurosurgery, Universitatsklinikum Giessen und Marburg, \\ Klinikstrasse 33 Giessen 35392, Germany \\ (e-mail: michael.bender@neuro.med.uni-giessen.de).
}

J Neurol Surg A 2020;81:17-27.

\begin{abstract}
Keywords

- transforaminal endoscopic surgery

- lumbar disk herniation

- learning curve

- university hospital setting

Objective Microsurgical diskectomy/sequestrectomy is the standard procedure for the surgical treatment of lumbar disk herniations. The transforaminal endoscopic sequestrectomy technique is a minimally invasive alternative with potential advantages such as minimal blood loss and tissue damage, as well as early mobilization of the patient. We report the implementation of this technique in a German university hospital setting.

Methods One single surgeon performed transforaminal endoscopic sequestrectomy from February 2013 to July 2016 for lumbar disk herniation in 44 patients. Demographic as well as perioperative, clinical, and radiologic data were analyzed from electronic records. Furthermore, we investigated complications, intraoperative change of the procedure to microsurgery, and reoperations. The postoperative course was analyzed using the Macnab criteria, supplemented by a questionnaire for follow-up. Pre- and postoperative magnetic resonance imaging volumetric analyses were performed to assess the radiologic efficacy of the technique.

Results Our study population had a median age of 52 years. The median follow-up was 15 months, and the median length of hospital stay was 4 days. Median duration of surgery was 100 minutes with a median blood loss of $50 \mathrm{~mL}$. Surgery was most commonly performed at the L4-L5 level (63\%) and in caudally migrated disk herniations (44\%). In six patients, surgery was performed for recurrent disk herniations. The procedure had to be changed to conventional microsurgery in four patients. We observed no major complications. Minor complications occurred in six patients, and in four patients a reoperation was performed. Furthermore, a significantly lower Oswestry Disability Index score $(p=0.03)$, a lower Short Form 8 Health Survey (SF-8) score $(p=0.001)$, a lower visual analog scale (VAS) lower back pain score $(p=0.03)$ and VAS leg pain score $(p=0.0008)$ at the 12-month follow-up were observed in comparison with the preoperative examination. In MRI volumetry, we detected a median postoperative volume reduction of the disk herniation of $57.1 \%(p=0.02)$.

Conclusions The transforaminal endoscopic sequestrectomy can be safely implemented in a university hospital setting in selected patients with primary and recurrent lumbar disk herniations, and it leads to good clinical and radiologic results. However, learning curve, caseload, and residents' microsurgical training requirements clearly affect the implementation process.
\end{abstract}

received

October 18, 2018

accepted after revision

February 20, 2019

published online

August 29, 2019 (c) 2020 Georg Thieme Verlag KG

Stuttgart · New York
DOI https://doi.org/

10.1055/s-0039-1694040. ISSN 2193-6315. 


\section{Introduction}

Microdiskectomy is a widely used and effective operation to treat lumbar disk herniations. ${ }^{1-3}$ However, muscular injury, facet joint violation, and epidural fibrosis can cause late sequelae. ${ }^{4}$ To overcome these problems, minimally invasive techniques such as transforaminal endoscopic sequestrectomy using the transforaminal endoscopic surgical system (TESSYS; Joimax GmbH, Karlsruhe, Germany) were have been established in recent years and are getting increasingly popular. ${ }^{5-9}$ Potential advantages of endoscopic diskectomy are less blood loss, lower rate of cerebrospinal fluid (CSF) fistulas and wound infections, as well as shorter length of hospital stay and recovery time compared with microsurgical diskectomy. ${ }^{10-14}$ Furthermore, in a systematic review by Nellensteijn et al, clinical results were comparable between transforaminal endoscopic surgery and microdiskectomy. ${ }^{9}$ Despite several advantages, endoscopic diskectomy has a significant learning curve (e.g., with longer durations of surgery and a higher reoperation rate). ${ }^{11,14}$ The technique is mostly performed in private practice or highly specialized spine surgery departments with or without only limited resident teaching obligations.

In contrast, microdiskectomy is the standard procedure for lumbar disk herniation surgery at our university hospital, and it is a requirement for our residents to be proficient in this procedure at the end of their training. However, due to its potential advantages, we recognized the need to innovate and integrate contemporary spinal endoscopy into our residency training program. This study was designed to demonstrate our experiences and pitfalls from the first 3 years after implementation of transforaminal endoscopic diskectomy in a German university hospital setting.

\section{Patients and Methods}

\section{Study Design}

In February 2013, transforaminal endoscopic sequestrectomy using TESSYS was introduced in our department. The current study includes 44 patients who were operated on between February 2013 and July 2016. The study protocol was approved by the institutional ethics board (No. 192/14). We included all patients with a lumbar disk herniation and an indication for surgery who (1) were judged to be suitable for a TESSYS operation by the senior spine surgeon (K.S.), and (2) gave their consent after information about the alternative of a microdiskectomy. Demographic, perioperative, and radiologic data as well as complications, intraoperative changes of the procedure to microsurgery, and reoperations were extracted from electronic records and Picture Archiving and Communication System (PACS).

\section{Follow-up}

Postoperative outcome was analyzed using the Macnab criteria, ${ }^{15}$ the return-to-work rate, the analgesic medication, and the overall satisfaction with help of a questionnaire. Overall satisfaction was assessed with a two-point scale: (1) I would consider the same operation again, or (2) I would not want to be operated again with the TESSYS technique. The mode of analgesic medication was determined by using a 4point scale: (1) no analgesic medication, (2) less analgesic medication, (3) same analgesic medication, and (4) more analgesic medication.

The final 11 patients of our study cohort operated on between June 2015 and July 2016 were additionally analyzed in a prospective manner. The Oswestry Disability Index (ODI), horizontal visual analog scale (VAS) for lower back pain and leg pain, and Short Form 8 (SF-8) Health Survey for quality-of-life evaluation were used at discharge, 6 weeks after surgery, as well as at 12 months after surgery. ${ }^{16-18}$

\section{Procedure}

In this study all endoscopic transforaminal lumbar sequestrectomies were performed with the TESSYS method under general anesthesia by one senior neurosurgeon with a subspecialization in spine surgery and fellowship training in minimally invasive spinal procedures (K.S.). All patients were treated in the prone position.

After detection of the correct surgical level with the C-arm (Veradius, Philips GmbH, Hamburg, Germany) and adjustment of the operating table (radiograph criteria: spinous processes in line and pedicle eyes symmetrical and clearly visible in anteroposterior [AP] views, with no double configuration of posterior vertebral body walls or pedicles in lateral views), the skin was sterilized and draped in a standard fashion. A hollow needle was inserted posterolaterally between 10 and $15 \mathrm{~cm}$ from the midline depending on the surgical level, the localization of the sequester, and the physiognomy of the patient and was advanced into the lateral neuroforamen under radiographic control. A Seldinger wire was then introduced into the needle, and, after removal of the needle, a linear skin incision of $\sim 0.8 \mathrm{~cm}$ was performed. A bent rod was then advanced transforaminally with the Seldinger technique into the anterior spinal canal (-Fig. 1) just passing the midline, followed by sequential dilation of the transforaminal trajectory with different tubes and sequential reaming of the caudo-posterior neuroforamen. Finally, the working cannula was placed in the vicinity of the pathology (-Fig. 2). All approach steps were conducted under repetitive radiographic control.

As a next step, an endoscope with a 30-degree view (6.3 $\mathrm{mm}$ outer diameter), and a working, an irrigation and a suction channel was then inserted through the working cannula. After identification of the pedicle, the dural sac, and the exiting nerve root, the herniated disk was identified, mobilized, and removed with different hooks and forceps (-Figs. 3 and 4). Hemostasis was performed using a radiofrequency probe (VaporFlex; Joimax GmbH, Karlsruhe, Germany). After complete removal of the herniated disk tissue, the endoscope and the working cannula were removed. The skin was closed by single sutures (-Fig. 5). No specific measures were taken in cases with a dural tear.

Mobilization was started immediately after surgery, and physiotherapy was initiated on postoperative day 1. Preoperative analgesic medication was continued 3 days after 


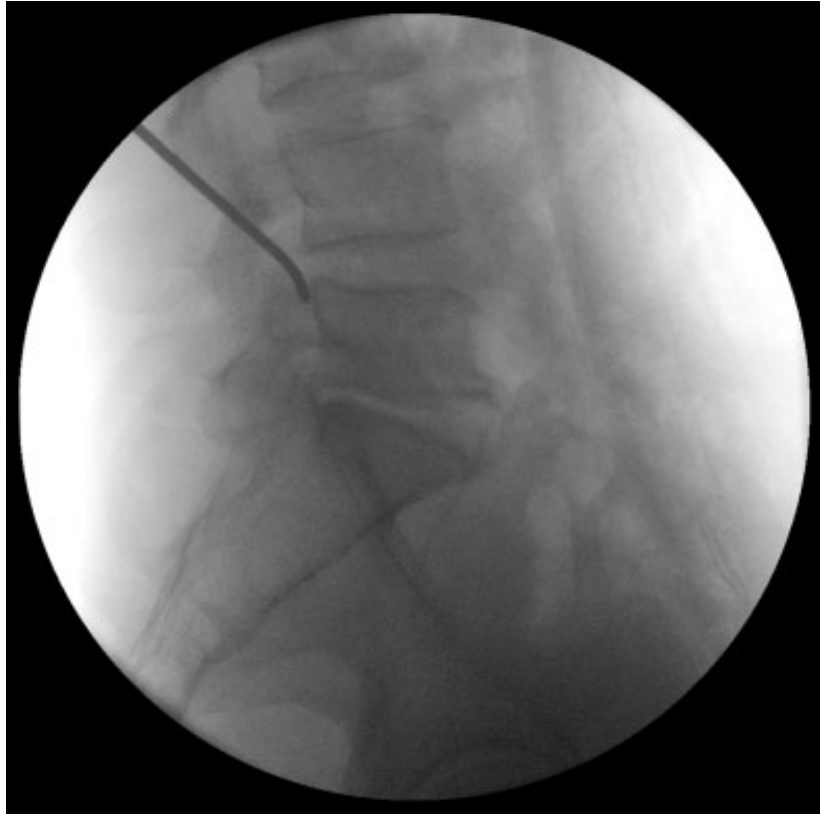

Fig. 1 Intraoperative lateral radiographic view after transforaminal insertion of a bent rod into the anterior epidural space at level L4-L5.

surgery and was subsequently reduced as required thereafter.

\section{MRI Volumetric Analysis}

\section{Imaging}

Magnetic resonance imaging (MRI) was performed on a 3-T MR Scanner (Verio; Siemens, Erlangen, Germany) equipped with 4 channels of a 12-channel surface coil. The thoracolumbar spine of each patient was imaged using sagittal T2weighted sequences (TR/TE, 3,000/104 ms, field of view

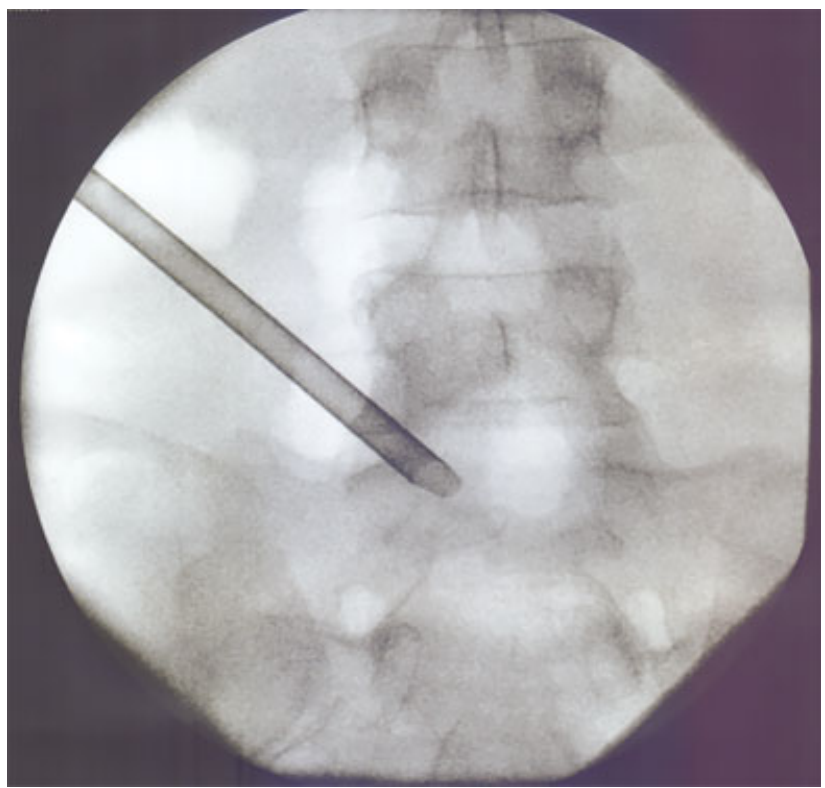

Fig. 2 Intraoperative anteroposterior radiographic visualization of the working cannula at level L5-S1 with its opening just medial to the pedicle.

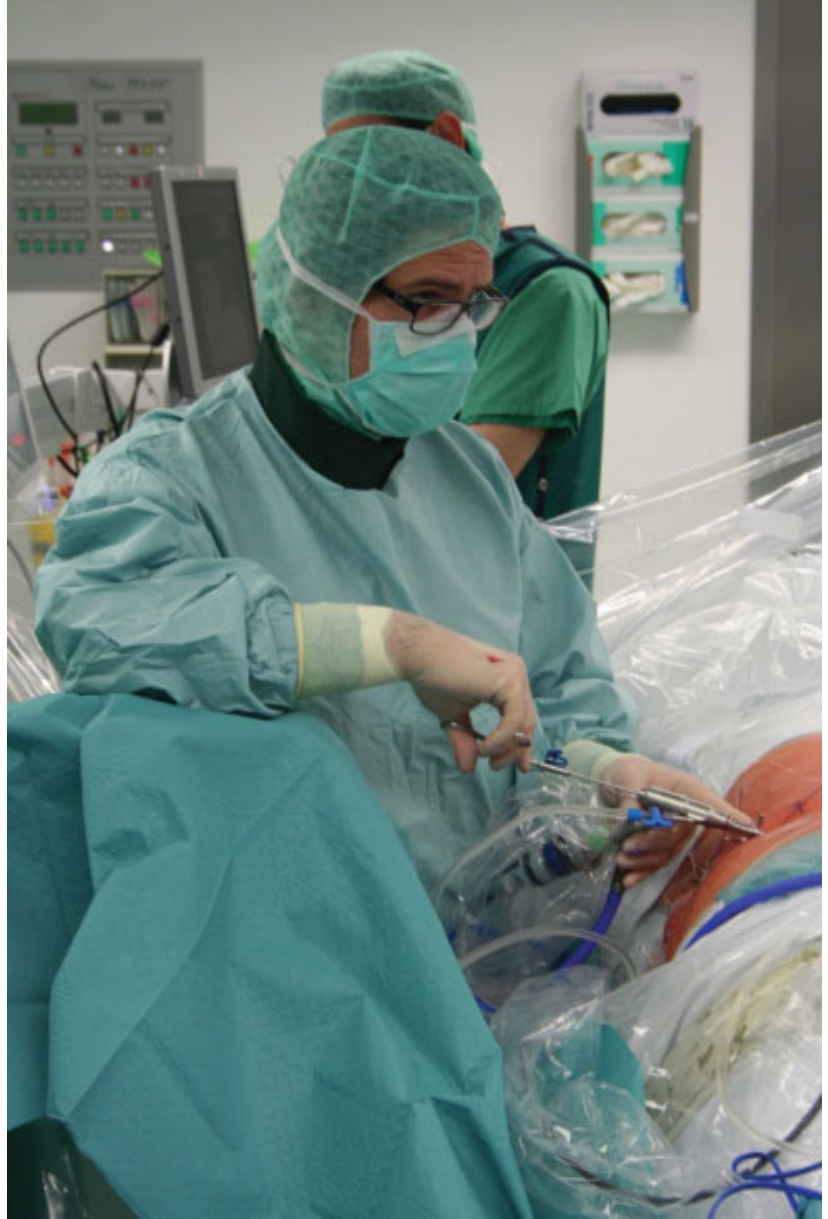

Fig. 3 Intraoperative setting. Removal of a disk herniation with endoscopic forceps.

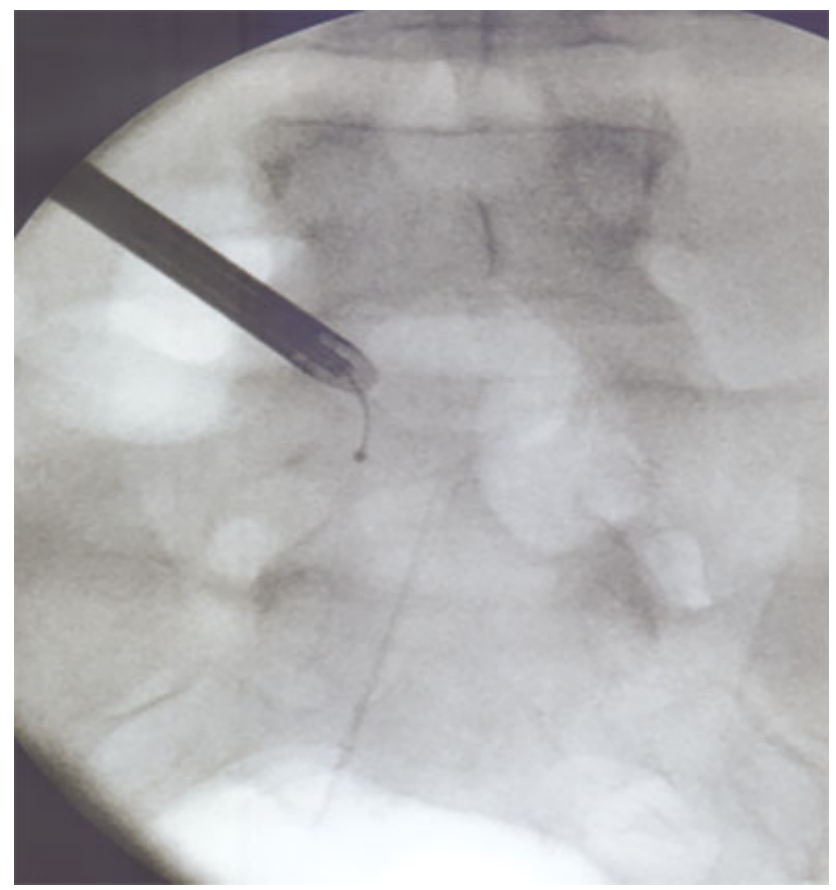

Fig. 4 Intraoperative anteroposterior radiographic visualization of an endoscopic telescope hook used to mobilize a disk herniation just medial to the $\mathrm{S} 1$ pedicle. 


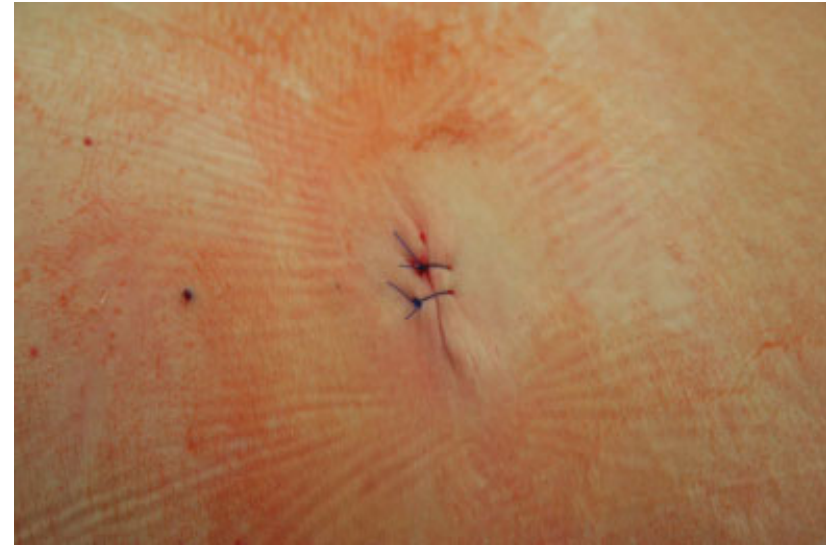

Fig. 5 The $\sim 0.8-\mathrm{cm}$-long skin incision was closed by two single sutures.

[FOV] $280 \times 280$, slice thickness $2 \mathrm{~mm}$ ) and constructive interference in steady state (CISS) sequences (TR/TE 5,51/ $2,39 \mathrm{~ms}$, FOV $0.7 \mathrm{~mm}$ isotropic voxels) preoperatively and between postoperative day 1 and 3 in the final 11 patients of our cohort in a prospective manner.

\section{Volumetric Analysis}

MR images were viewed and postprocessed by an experienced neuroradiologist (C.G.) on an PACS workstation (INFINITT Healthcare Co., Brussels, Belgium). The sagittal slices of the T2-weighted sequences were matched with the axial slices of the CISS sequence. With the aid of the CISS sequence, the individual midline was identified in each data set (-Fig. 6). Only those sagittal slices that represented herniated disk material of the most affected side were used for volumetry (i.e., slices were identified from the midline to the most lateral slice just containing herniated disk material). The neuroradiologist manually outlined the herniated disk in these slices as

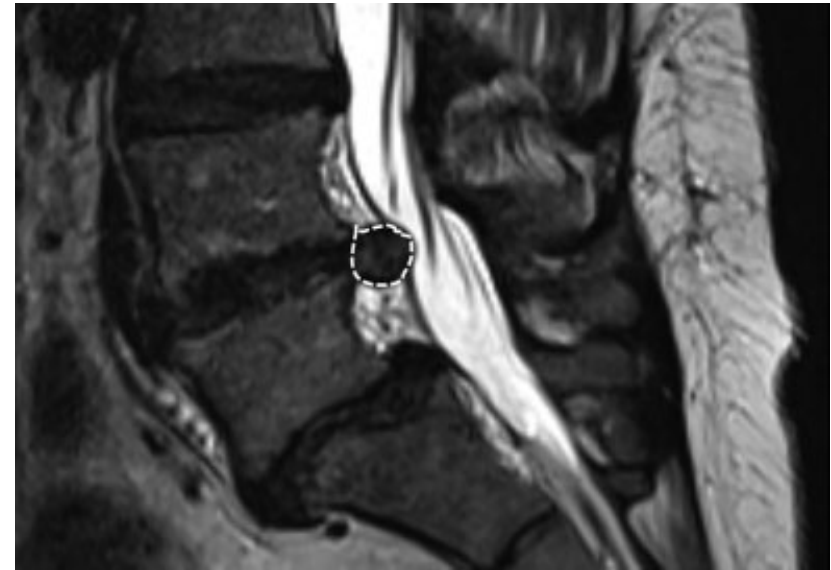

Fig. 7 The sagittal slices of the T2-weighted sequences. A radiologist manually outlined the herniated disk in these slices.

shown in - Fig. 7. The volume of the disk material initially measured pre- and postoperatively as an area in sagittal slices was calculated as the product of these areas, the number of the respective adjacent slices, and the slice thickness $(2 \mathrm{~mm})$.

\section{Statistical Analysis}

For data analysis and graphic illustration, Graph Pad Prism v.5 (GraphPad Software, Inc., La Jolla, California, United States) was used. Data were expressed as median plus or minus range. The chi-square test (categorical variables) and the Mann-Whitney rank sum test (continuous variables) were used for intergroup comparisons. A $p<0.05$ was defined as the level of significance.

\section{Results}

Patients of our study group had a median age of 52 years (range: $25-75$ years). The median duration of hospital stay

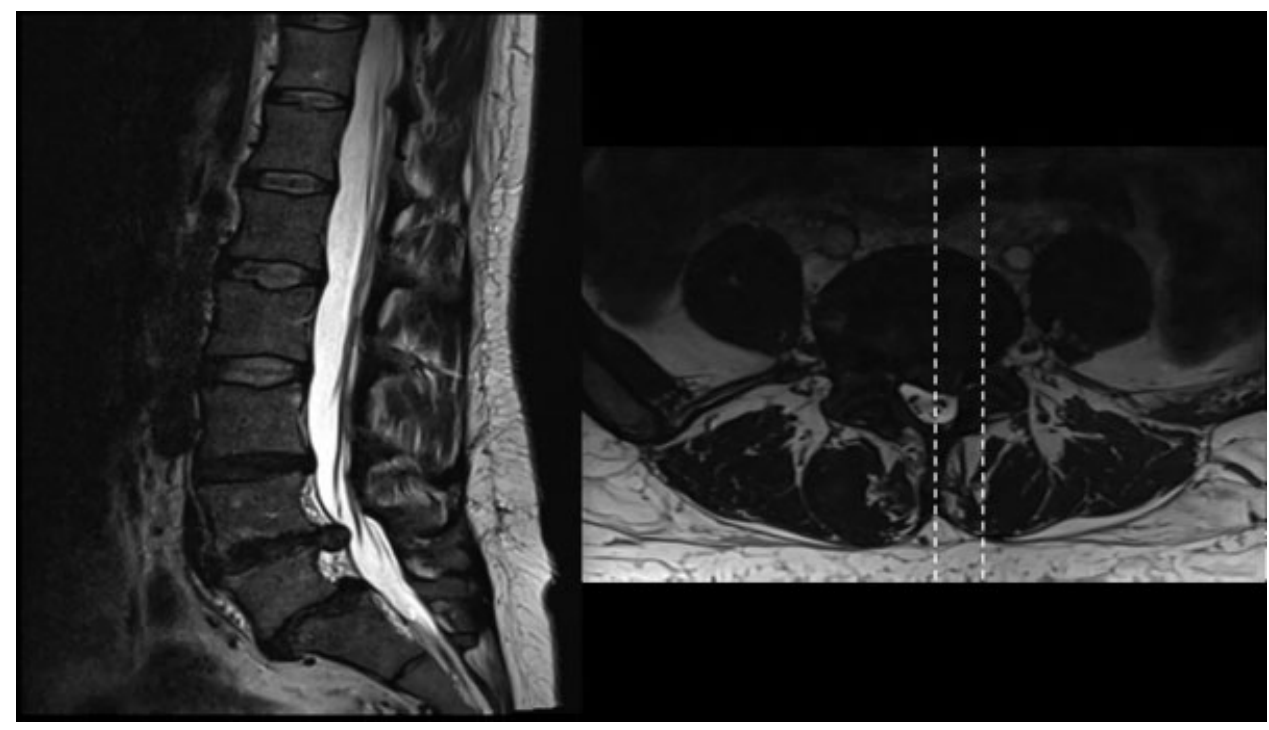

Fig. 6 The sagittal and axial slices of the T2-weighted constructive interference in steady state (CISS) sequences. With help of the CISS sequence, the individual midline was identified in each data set. 
was 4 days (range: 1-13 days), and the median follow-up was 15 months (range: 7-30 months). A total of 40 patients were available for follow-up (one patient had died, with no association to surgery, two patients did not respond to the questionnaire, and one patient was lost to follow-up). Baseline data are summarized in - Table $\mathbf{1}$.

\section{Perioperative Data}

Surgery was mostly performed at level L4-L5 (63\%) and in caudally migrated disk herniations (44\%). In 42 patients, surgery was performed at one level, and 2 patients were operated on at two levels. Neurophysiologic monitoring was used in seven patients; however, monitoring was abandoned later because we did not find any benefit from it. In the first two patients, operations were supported by an external surgeon with vast experience in transforaminal endoscopic surgery; 13 further operations were supported by an experienced application specialist from the Joimax Company with a scrub nurse background.

Table 1 Baseline data of the study population ${ }^{a}$

\begin{tabular}{|c|c|}
\hline & $\begin{array}{l}\text { Study population } \\
(n=44)\end{array}$ \\
\hline \multicolumn{2}{|l|}{ Demographics } \\
\hline Median age, y (range) & $52(25-78)$ \\
\hline Women, $n(\%)$ & $18(41)$ \\
\hline Median BMI, kg/m² (range) & $28(20-47)$ \\
\hline Median ASA score (range) & $2(1-3)$ \\
\hline $\begin{array}{l}\text { Median duration of } \\
\text { symptoms, wk (range) }\end{array}$ & $13(1-53)$ \\
\hline \multicolumn{2}{|l|}{ Spinal level of disk herniation, $\boldsymbol{n}(\%)$} \\
\hline L1-L2 & $1(2)$ \\
\hline L2-L3 & $1(2)$ \\
\hline L3-L4 & $5(11)$ \\
\hline L4-L5 & $29(63)$ \\
\hline L5-S1 & $10(22)$ \\
\hline \multicolumn{2}{|l|}{ Localization of disk herniation, $n(\%)$} \\
\hline Right side & $26(59)$ \\
\hline Left side & $18(41)$ \\
\hline Cranial sequestration & $1(2)$ \\
\hline Caudal sequestration & $23(50)$ \\
\hline Mediolateral sequestration & $16(35)$ \\
\hline Intraforaminal sequestration & $2(4)$ \\
\hline Intra-extraforaminal sequestration & $1(2)$ \\
\hline Extraforaminal sequestration & $3(7)$ \\
\hline \multicolumn{2}{|l|}{ Type of disk herniation, $n$ (\%) } \\
\hline Primary disk herniation & $38(86)$ \\
\hline Recurrent disk herniation & $6(14)$ \\
\hline
\end{tabular}

Abbreviations: ASA, American Society of Anesthesiologists; BMI, body mass index.

an two patients, surgery was performed at two levels.
The median duration of surgery was 100 minutes (range: 40-234 minutes) with a median blood loss of $50 \mathrm{~mL}$ (range: $5-1,005 \mathrm{~mL}$ ). We observed no significant difference regarding duration of surgery $(p=0.50)$ and blood loss $(p=0.56)$ between the first 22 and last 22 patients. We observed a median intraoperative radiation dose of $15.8 \mathrm{cGy} \mathrm{cm}{ }^{2}$ (range: $3.3-318 \mathrm{cGy} \mathrm{\textrm {cm } ^ { 2 }}$ ).

The procedure had to be changed to microsurgery in four patients: In two patients who were operated on at level L4L5, a transmuscular tubular approach was applied due to intraspinal bleeding that was not adequately controlled by endoscopy. In two further patients who were operated at level L5-S1, a high iliac crest in conjunction with neuroforaminal stenosis and ligamentous hypertrophy prohibited a controlled endoscopic removal of the disk herniation, and the procedure was changed to a subperiosteal specular approach.

Our study population experienced no major complications. In six patients the following minor complications occurred: five patients exhibited a temporary neurologic deficit (three patients with worsened and two patients with new paresis), and one patient experienced an early recurrent disk herniation 2 days after surgery. A dural tear occurred in six patients; however, there was no postoperative CSF fistula in our series.

Reoperations were performed in four patients due to one early recurrent disk herniation, one late recurrent disk herniation 8 weeks after surgery, and two new neurologic deficits on the day of the operation and assumed postoperative hemorrhage on MRI that could not, however, be confirmed on surgical inspection.

\section{Follow-up}

At follow-up, the median Macnab score was 2 (range: 1-4). We determined an overall satisfaction of $90 \%$. A total of $95 \%$ of the formerly working patients were able to return to work. No lower back pain or reduced pain was observed in $80 \%$ of the patients, and $85 \%$ had no or reduced leg pain. A reduction or no further need for analgesic medication was observed in $95 \%$ of the patients. In the 11 prospectively analyzed patients, we observed a significantly lower ODI score $(p=0.03)$, SF-8 score $(p=0.001)$, VAS lower back pain score $(p=0.03)$, and VAS leg pain score $(p=0.0008)$ in comparison with the preoperative examination. - Table 2 summarizes the results of the prospective follow-up examinations.

\section{MRI Volumetric Analysis}

Volumetric analysis of the preoperative and postoperative MRI scans was performed in 10 patients; in one case we abandoned the preoperative volumetric scan, due to an emergency indication for surgery. The median preoperative disk herniation volume was $1.4 \mathrm{~cm}^{3}$ (range: $0.3-$ $1.9 \mathrm{~cm}^{3}$ ) compared with a postoperative volume of $0.6 \mathrm{~cm}^{3}$ (range: $0.2-1.4 \mathrm{~cm}^{3}$ ). We found a statistically significant disk volume reduction of $57.1 \%(p=0.02)$, as shown in -Fig. 8. 
Table 2 Follow-up examination of prospectively analyzed patients $(n=11)^{\mathrm{a}}$

\begin{tabular}{|c|c|c|c|}
\hline & Median & Range & $p$ Value \\
\hline \multicolumn{4}{|l|}{ ODI } \\
\hline Preoperative & 25 & $10-39$ & \\
\hline At discharge & 21 & $1-42$ & 0.32 \\
\hline 6-wk FU & 12 & $0-40$ & 0.06 \\
\hline 12-mo FU & 6.5 & $0-29$ & 0.003 \\
\hline \multicolumn{4}{|l|}{ SF-8 } \\
\hline Preoperative & 33 & $23-39$ & \\
\hline At discharge & 29 & $23-39$ & 0.45 \\
\hline 6-wk FU & 25 & $8-43$ & 0.1 \\
\hline 12-mo FU & 21.5 & $12-32$ & 0.001 \\
\hline \multicolumn{4}{|c|}{ VAS lower back pain } \\
\hline Preoperative & 5 & $2-9$ & \\
\hline At discharge & 2 & $1-4$ & 0.01 \\
\hline 6-wk FU & 3 & $1-10$ & 0.05 \\
\hline 12-mo FU & 2 & $1-7$ & 0.03 \\
\hline \multicolumn{4}{|l|}{ VAS leg pain } \\
\hline Preoperative & 6 & $2-10$ & \\
\hline At discharge & 2 & $1-10$ & 0.01 \\
\hline 6-wk FU & 3 & $1-8$ & 0.008 \\
\hline 12-mo FU & 2 & $1-5$ & 0.0008 \\
\hline
\end{tabular}

Abbreviations: FU, follow-up; ODI, Oswestry Disability Index, SF-8, Short Form-8 Health Survey, VAS, visual analog scale.

${ }^{a}$ We observed a significantly lower ODI score $(p=0.03)$, a lower SF-8 score $(p=0.001)$, and a lower VAS lower back pain score $(p=0.03)$ and VAS leg pain score $(p=0.0008)$ at the 12 -month FU examination in comparison with the preoperative examination. Statistical analysis was performed with the Mann-Whitney $U$ test.

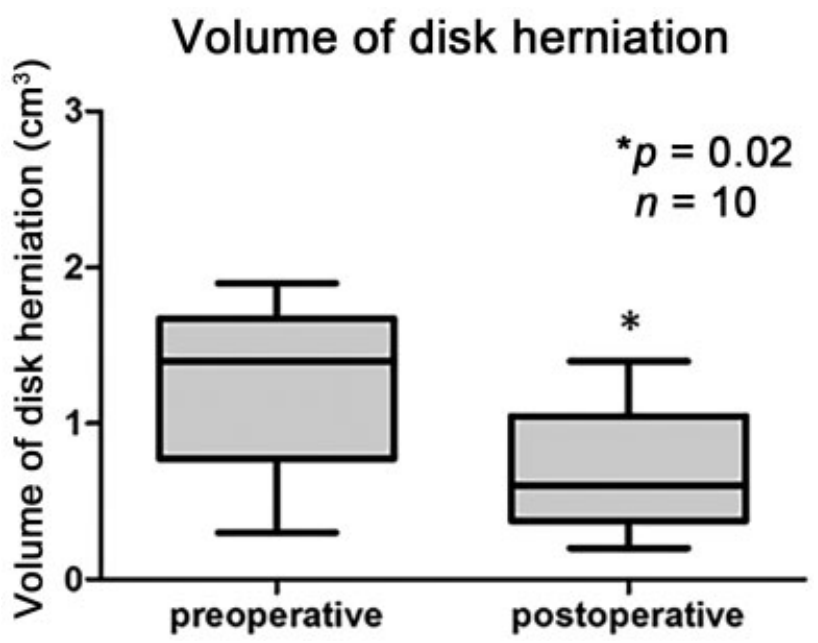

Fig. 8 Magnetic resonance imaging volumetric analysis. We observed a significant volume reduction of disk herniation volume in the postoperative volumetric analysis $(p=0.02)$.

\section{Discussion}

Advantages of Endoscopic Lumbar Diskectomy

Minimal muscle trauma and blood loss, low rates of wound infections and CSF fistulas, as well as shorter hospital stay and recovery time, are potential advantages of transforaminal endoscopic diskectomy compared with conventional techniques. ${ }^{11-14}$ Furthermore, microdiskectomy mostly requires muscle retraction, yellow ligament resection, and bone resection of the facet joint and/or the lamina that can lead to epidural fibrosis or segmental instability. $11,13,14,19$ These obvious potential advantages of the transforaminal endoscopic approach led us to introduce the TESSYS technique at our neurosurgical department. Our results also underline the advantages because no patient in our study population had a wound infection or CSF fistula, and the median blood loss was low. Furthermore, the median hospital stay of our study population was 4 days, which is low compared with 7 days that we found in a cohort of microdiskectomy patients we operated on during the same time interval as our study population (data not shown).

\section{Clinical and Radiologic Outcome}

Several studies reported that transforaminal endoscopic diskectomy and microdiskectomy are both effective methods to treat a lumbar disk herniation, as also shown in -Table 3. ${ }^{9,11,12,14,20-23}$ A large systematic review of 39 studies concluded that there are no differences between transforaminal endoscopic diskectomy and microdiskectomy with regard to pain, overall improvement, patient satisfaction, recurrence rate, complications, and reoperations. ${ }^{9}$ However, the authors criticized the poor scientific evidence of the current literature. Our clinical results are comparable with other studies on endoscopic and microsurgical diskectomy and showed a clear clinical improvement of Macnab, ODI, and VAS at 15 and 12 months after surgery, respectively. Furthermore, the overall satisfaction was $90 \%$, $95 \%$ of the patients needed less or no analgesic medication, and $95 \%$ of the previously employed people were able to return to work, indicating a clinically effective procedure including patients with recurrent disk herniations.

We observed a statistically significant postoperative reduction of disk volume of $57.1 \%$ at the MRI volumetric analysis. Wang et al reported a residual mass of $93.6 \%$ on MRI 1 week after endoscopic diskectomy. ${ }^{24}$ After lumbar microdiskectomy, a rate of $80 \%$ residual epidural tissue on MRI scans on the third day after surgery was reported. ${ }^{25}$ Annertz et al even described a nerve root involvement of $100 \%$ on MRI 5 days after surgery. ${ }^{26}$ However, the comparability of these different studies is very limited because different methods for quantifying residual disk volume were used, and the interpretation of an early postoperative MRI can be very difficult. Residual nerve root compression is common, but the correlation with clinical symptoms is poor. ${ }^{24,25}$ However, our results show a relevant reduction of disk herniation volume and indicate that good clinical results can be achieved even without complete removal of the herniated disk. 
Table 3 Outcome after endoscopic versus microdiskectomy: Literature review

\begin{tabular}{|c|c|c|c|c|c|}
\hline Study & Surgical technique & $\begin{array}{l}\text { Recurrent } \\
\text { symptomatic } \\
\text { disk herniation, \% }\end{array}$ & $\begin{array}{l}\text { Reoperation } \\
\text { rate, \% }\end{array}$ & $\begin{array}{l}\text { Complication } \\
\text { rate, \% }\end{array}$ & $\begin{array}{l}\text { Clinical outcome/Satisfac- } \\
\text { tion }\end{array}$ \\
\hline \multicolumn{6}{|c|}{ Endoscopic lumbar diskectomy } \\
\hline $\begin{array}{l}\text { Our data } \\
n=44\end{array}$ & $\begin{array}{l}\text { Transforaminal en- } \\
\text { doscopic } \\
\text { sequestrectomy }\end{array}$ & 2.3 & 9.1 & 13.6 & $\begin{array}{l}\text { FU: } 15 \text { mo } \\
\text { Macnab score: } 90 \% \text { excel- } \\
\text { lent or good } \\
\text { FU: } 12 \text { mo } \\
\text { ODI reduction: } 25 \text { preop./ } \\
6.5 \text { postop. } \\
\text { SF-8 reduction: } 33 \text { preop./ } \\
21.5 \text { postop. } \\
\text { VAS leg pain reduction: } 6 \\
\text { preop./2 postop. } \\
\text { VAS back pain reduction: } 6 \\
\text { preop./2 postop. }\end{array}$ \\
\hline $\begin{array}{l}\text { Ramsbacher } \\
\text { et al } \\
n=39\end{array}$ & $\begin{array}{l}\text { Transforaminal en- } \\
\text { doscopic } \\
\text { sequestrectomy }\end{array}$ & NS & 10 & 5.1 & $\begin{array}{l}\text { FU: } 6 \text { wk } \\
\text { VAS leg pain reduction: } 6.7 \\
\text { preop./0.8 postop. } \\
\text { VAS back pain reduction: } \\
5.1 \text { preop./1.3 postop. }\end{array}$ \\
\hline $\begin{array}{l}\text { Yeung et } \mathrm{al}^{9} \\
n=307\end{array}$ & $\begin{array}{l}\text { Posterolateral en- } \\
\text { doscopic excision } \\
\text { for lumbar disk } \\
\text { herniation }\end{array}$ & 0.7 & 4.6 & 3.9 & $\begin{array}{l}\text { FU: } 19 \text { mo } \\
\text { Macnab score: } 84 \% \text { excel- } \\
\text { lent or good }\end{array}$ \\
\hline $\begin{array}{l}\text { Eustacchio et } \mathrm{al}^{9} \\
n=122\end{array}$ & $\begin{array}{l}\text { Endoscopic percu- } \\
\text { taneous transfora- } \\
\text { minal treatment }\end{array}$ & 12 & 27 & 9 & $\begin{array}{l}\text { FU: } 35 \text { mo } \\
\text { Macnab score: } 45 \% \text { excel- } \\
\text { lent and } 27 \% \text { good }\end{array}$ \\
\hline $\begin{array}{l}\text { Morgenstern et } \mathrm{al}^{9} \\
n=144\end{array}$ & $\begin{array}{l}\text { Endoscopic spine } \\
\text { surgery }\end{array}$ & NS & 5.6 & 9 & $\begin{array}{l}\text { FU: } 24 \text { mo } \\
\text { Macnab score: } 83 \% \text { excel- } \\
\text { lent or good }\end{array}$ \\
\hline $\begin{array}{l}\text { Schubert et } \mathrm{al}^{9} \\
n=558\end{array}$ & $\begin{array}{l}\text { Transforaminal } \\
\text { nucleotomy with } \\
\text { foraminoplasty }\end{array}$ & 3.6 & 3.6 & 0.7 & $\begin{array}{l}\text { FU: } 12 \text { mo } \\
\text { Macnab score: } 51 \% \text { excel- } \\
\text { lent and } 43 \% \text { good } \\
\text { VAS leg pain reduction: } 8.4 \\
\text { preop./1.0 postop. } \\
\text { VAS back pain reduction: } \\
8.6 \text { preop./1.4 postop. }\end{array}$ \\
\hline $\begin{array}{l}\text { Ruetten et } \mathrm{al}^{9} \\
n=517\end{array}$ & $\begin{array}{l}\text { Extreme-lateral } \\
\text { transforaminal } \\
\text { approach }\end{array}$ & 6.9 & 6.9 & 0 & $\begin{array}{l}\text { FU: } 12 \text { mo } \\
\text { VAS leg pain reduction: } 7.1 \\
\text { preop./0.8 postop. } \\
\text { VAS back pain reduction: } \\
1.8 \text { preop./1.6 postop. } \\
\text { Functional status (ODI) re- } \\
\text { duction: } 78 \text { preop./20 } \\
\text { postop. }\end{array}$ \\
\hline $\begin{array}{l}\text { Jang et } \mathrm{al}^{9} \\
n=35\end{array}$ & $\begin{array}{l}\text { Transforaminal per- } \\
\text { cutaneous endo- } \\
\text { scopic diskectomy }\end{array}$ & 0 & 8.6 & 17 & $\begin{array}{l}\text { FU: } 18 \text { mo } \\
\text { Macnab score } 86 \% \text { excellent } \\
\text { or good }\end{array}$ \\
\hline $\begin{array}{l}\text { Tzaan }^{9} \\
n=134\end{array}$ & $\begin{array}{l}\text { Transforaminal per- } \\
\text { cutaneous endo- } \\
\text { scopic lumbar } \\
\text { diskectomy }\end{array}$ & 0.7 & 4.5 & $6.0 \%$ & $\begin{array}{l}\text { FU: } 38 \text { mo } \\
\text { Macnab score: } 28 \% \text { excel- } \\
\text { lent and } 61 \% \text { good }\end{array}$ \\
\hline $\begin{array}{l}\text { Choi et } \mathrm{al}^{9} \\
n=41\end{array}$ & $\begin{array}{l}\text { Extraforaminal tar- } \\
\text { geted } \\
\text { fragmentectomy }\end{array}$ & 5.1 & 7.7 & 5.1 & $\begin{array}{l}\text { FU: } 34 \text { mo } \\
\text { VAS leg pain reduction: } 8.6 \\
\text { preop./1.9 postop. } \\
\text { Functional status (ODI) re- } \\
\text { duction: } 66.3 \text { preop./11.5 } \\
\text { postop. }\end{array}$ \\
\hline
\end{tabular}


24 Transforaminal Endoscopic Lumbar Sequestrectomy Bender et al.

Table 3 (Continued)

\begin{tabular}{|c|c|c|c|c|c|}
\hline Study & Surgical technique & $\begin{array}{l}\text { Recurrent } \\
\text { symptomatic } \\
\text { disk herniation, \% }\end{array}$ & $\begin{array}{l}\text { Reoperation } \\
\text { rate, \% }\end{array}$ & $\begin{array}{l}\text { Complication } \\
\text { rate, } \%\end{array}$ & $\begin{array}{l}\text { Clinical outcome/Satisfac- } \\
\text { tion }\end{array}$ \\
\hline \multicolumn{6}{|c|}{ Conventional lumbar (micro)diskectomy } \\
\hline $\begin{array}{l}\text { Peul et al } \\
n=141\end{array}$ & $\begin{array}{l}\text { Microscopic unilat- } \\
\text { eral transforaminal } \\
\text { approach }\end{array}$ & 3.2 & 3.2 & 1.6 & $\begin{array}{l}\text { FU: } 52 \text { wk } \\
\text { SF-36 Physical Function re- } \\
\text { duction: } 33.9 \text { preop./84.2 } \\
\text { postop. }\end{array}$ \\
\hline $\begin{array}{l}\text { Weinstein et } \mathrm{al}^{21} \\
n=545 \text { (observa- } \\
\text { tional cohort) }\end{array}$ & Open diskectomy & 7 & NS & 3 & $\begin{array}{l}\text { FU: } 4 \text { y } \\
\text { ODI reduction: } 49.3 \text { preop./ } \\
11.2 \text { postop. } \\
\text { SF-36 Physical Function re- } \\
\text { duction: } 37.9 \text { preop./44.6 } \\
\text { postop. } \\
\text { Work status: working: } \\
84.4 \%\end{array}$ \\
\hline $\begin{array}{l}\text { Hsu et } \mathrm{al}^{14} \\
n=66\end{array}$ & $\begin{array}{l}\text { Open } \\
\text { microdiskectomy }\end{array}$ & NS & 6.1 & 1.5 & $\begin{array}{l}\text { FU: NS } \\
\text { VAS reduction: } 9 \text { preop./1.3 } \\
\text { postop } \\
\text { ODI reduction: } 32 \text { preop./ } \\
3.3 \text { postop }\end{array}$ \\
\hline $\begin{array}{l}\text { Strömqvist et al }{ }^{22} \\
n=12,840 \text { (cohort } \\
\text { "younger") }\end{array}$ & Lumbar diskectomy & NS & NS & 5 & $\begin{array}{l}\text { FU: } 12 \text { mo } \\
\text { VAS leg pain reduction: } 66 \\
\text { preop./22 postop } \\
\text { VAS back pain reduction: } 46 \\
\text { preop./ } 25 \text { postop. } \\
\text { ODI: } 20\end{array}$ \\
\hline $\begin{array}{l}\text { Gibson et al }{ }^{11} \\
N=70\end{array}$ & $\begin{array}{l}\text { Microscopic trans- } \\
\text { foraminal approach }\end{array}$ & 0 & 2.9 & 1.4 & $\begin{array}{l}\text { FU: } 2 \text { y } \\
\text { VAS affected leg reduction: } \\
5.8 \text { preop./3.5 postop. } \\
\text { VAS nonaffected leg reduc- } \\
\text { tion: } 0.7 \text { preop. } / 0.8 \text { postop. } \\
\text { VAS back pain reduction: } \\
4.6 \text { preop./3.0 postop. }\end{array}$ \\
\hline $\begin{array}{l}\text { Liu et } \mathrm{al}^{23} \\
n=69\end{array}$ & $\begin{array}{l}\text { Microscopic trans- } \\
\text { foraminal approach }\end{array}$ & 0 & 0 & 7.2 & $\begin{array}{l}\text { FU: } 2 \text { y } \\
\text { VAS leg pain reduction: } 6.9 \\
\text { preop./1.4 postop. } \\
\text { VAS back pain reduction: } \\
5.8 \text { preop./1.4 postop. }\end{array}$ \\
\hline
\end{tabular}

Abbreviations: FU, follow-up; NS, not specified, ODI: Oswestry Disability Index (range: 0-100), postop., postoperative; preop., preoperative; SF- 8: Short Form-8 Health Survey (range: 0-100), SF-36: Short Form-36 Health Survey (range: 0-100), VAS, visual analog scale (range: 0-10).

\section{Transition Process and Learning Curve}

The standard procedure for surgery of lumbar disk herniations at our department is a microdiskectomy using a transmuscular tubular or a subperiosteal specular approach. Residents are expected to be proficient in this procedure at the end of the German 6-year neurosurgical training program. In addition to these requirements, an increasing number of patients with uncomplicated lumbar disk herniations are now operated on in private practice, which leaves a lower overall number and more complex cases including revision surgery to university teaching hospitals like ours. All of these circumstances limit the caseload needed for the implementation of a new technique such as endoscopic diskectomy.

However, due to the various potential advantages, we decided to establish a spinal endoscopy program at our department. One experienced spine surgeon (K.S.), who is practiced in performing microsurgical procedures, was assigned to implement the technique. After a period of observation and a cadaver course, we started with the first transforaminal endoscopic procedure supported by an experienced surgeon. Furthermore, during the following 13 operations (and during two more operations at later time points) surgery was supported by an experienced application specialist who helped improve the surgical technique and eliminate systematic errors.

We observed a median duration of surgery of 100 minutes with no significant difference between the first and the final 22 patients $(p=0.5)$, indicating a flat learning curve. Hsu and coworkers, who also described their transition process from microdiskectomy to endoscopic diskectomy (interlaminar and transforaminal route), found an operation time of 86.5 
minutes in their first 57 patients that was almost twice as high (48.1 minutes) as in a parallel microdiskectomy group of patients who were operated on by the same surgeon. ${ }^{14}$ Martin-Láez et al found similar numbers during their transition from microsurgical diskectomy (operation time: 66 minutes) to microendoscopic diskectomy using the interlaminar approach (operation time: 100 minutes). ${ }^{27}$ Challenging learning curves of endoscopic lumbar diskectomy that include increased complication and reoperation rates, as well as recurrent disk herniations and the necessity of converting the procedure to microsurgery, were described by several authors. ${ }^{14,28-31}$

Despite our limited caseload, we were able to implement the technique without any major complications. Minor complications occurred in six patients (13.6\%) including a temporary new neurologic deficit in five patients and an early recurrent disk herniation in one patient. Temporary sensory and motor deficits are not uncommon after endoscopic diskectomy, and the rate of dura perforations can increase, particularly while mastering the learning curve. ${ }^{14,27,29,32} \mathrm{Hsu}$ et al found a nerve injury rate of $4.3 \%$ during their transition process; Singh et al reported new sensory deficits in $8.7 \%$ and new motor deficits in $17.4 \%$ of their patients. New deficits are found in patients with or without dura perforations, and the rates of CSF fistulas are generally low as they were in our series. ${ }^{14}$

Our complication rate is slightly higher than reported in most publications describing the transition and learning curve. However, the complication rate is naturally influenced by the number of patients in the respective series and the point of the learning curve that has been reached. Furthermore, the rates are difficult to compare due to the different endoscopic techniques and systems used. In our opinion, the highest risk for a dura and/or a neurologic injury exists during the placement of the approach rods or during reaming of the neuroforamen. In this phase, particularly if the instruments are placed too posteriorly or if the medial pedicle wall is not respected, contusion of the nerve roots can occur. Therefore, meticulous technique may help prevent neurologic deficits. Tips and tricks for beginners are offered later in this article. Operations under local anesthesia are an option to receive online patient feedback and might help prevent nerve injuries. ${ }^{33}$ However, an awake patient places the surgeon under stress and can negatively affect the workflow, particularly during the learning curve.

In our series, a reoperation was indicated in four patients (9\%) including one patient with an early recurrent disk herniation, one patient with a late recurrent disk herniation, and two patients with a new neurologic deficit and suspected postoperative hemorrhage on MRI. Several studies reported a reoperation rate in the range of 4.2 to $11 \%$ after endoscopic diskectomy that can increase up to $21 \%$ during the learning curve as found by Tenenbaum et al. Thus our results are comparable with the literature. ${ }^{11,30,34-37}$ Cong et al found a recurrence rate of $5.04 \%$ after endoscopic diskectomy in a meta-analysis, so our results with a rate of $2.3 \%$ are also comparable. ${ }^{13}$ A conversion to microdiskectomy was necessary in four (9\%) of our patients. Similar conversion rates during the learning were reported by Joswig et al (10\%) and by Lee and Lee (7.8\%). ${ }^{28,38}$ Reasons can be complications, reduced visibility, or challenging anatomy ${ }^{28}$ as in our series. Based on these facts, we recommend informing every patient about a potential conversion to microdiskectomy until the surgeon feels comfortable with the procedure and the learning curve is complete.

\section{Tips and Tricks for Beginners}

In our opinion there are several aspects to consider during the transition process to transforaminal endoscopic diskectomy:

- Adequate patient selection is an important step. We recommend starting transforaminal endoscopic surgery in patients with caudally migrated mediolateral disk herniations at the L4-L5 level or above. The trajectory to the disk herniation is easy and intuitive, and the iliac crest is not in the way.

If the surgeon feels more comfortable with the technique, disk herniations at the level L5-S1, intra- and extraforaminal herniations, and cranially migrated disk herniations can be approached.

The endoscopic technique should not be withheld from patients with recurrent disk herniations because the transforaminal approach allows the surgeon to mostly bypass the typical epidural fibrosis en route to the surgical target.

- A preoperative AP and lateral radiograph should be performed in patients with a herniation at the level L5-S1 to rule out a high iliac crest. The combination of a disk herniation at the L5-S1 disk level or a cranially migrated herniation in combination with a high iliac crest is not a case for beginners.

- We recommend an observation period and cadaver training before starting the first procedures. During the initial cases, discussion of the indication and supervision by an experienced spine surgeon is strongly advised. Also, during the first 10 to 20 cases and particularly if there are long time intervals between the operations, a follow-up visit and support of an application specialist might be helpful.

- Neurophysiologic monitoring is not helpful for a transforaminal endoscopic approach in our opinion.

- We identified three critical steps to avoid a nerve injury: (1) The small bent rod and the Seldinger wire should only just cross the midline on the AP radiograph. Slippage of these devices far to the contralateral side, which can easily happen in cases of a wide neuroforamen, places the contralateral nerve at risk. Alternatively, the small straight rod can be used and can be placed just medially to the medial pedicle wall. (2) The approach devices have to be placed in the anterior epidural space in strict vicinity to the posterior wall of the vertebral body to prevent a dura perforation. (3) The medial pedicle wall has to be meticulously respected during reaming of the neuroforamen.

\section{Limitations}

Our study had several limitations. The most important limitation is the retrospective study design with its well- 
known limitations. Determination of the outcome for the retrospective cohort was only possible at discharge and by a questionnaire because most of the patients did not present to the routine follow-up examinations. Another limitation is the absence of a proper control group treated with microscopic surgery to compare both methods. However, this was not the aim of our study. Furthermore, patients were very carefully selected because we only included patients in which a transforaminal endoscopic approach seemed to be technically feasible. Especially in patients with a marked neuroforaminal stenosis, a high iliac crest, or cranially migrated disk herniations, we performed a microscopic diskectomy procedure. In addition, MRI volumetric analysis was only performed in 10 patients. Nevertheless, we observed a significant reduction of disk volume herniation.

\section{Conclusion}

Implementation of the transforaminal endoscopic lumbar sequestrectomy technique in a university hospital setting is feasible and safe in selected patients with primary and recurrent disk herniations. However, several factors hinder the implementation process including the flat learning curve and the caseload that is significantly influenced by other competing team members and the residents' training requirements in microsurgery. As a result, only one surgeon can learn the technique at a time.

\section{Conflict of Interest}

Karsten Schöller reports personal fees from invited lectures at Medicon and Baxter outside the submitted work. The other authors have declared no conflicts of interest for this article.

\section{References}

1 Cheng YP, Lee KW, Lin PY, et al. Full-endoscopic interlaminar removal of chronic lumbar epidural hematoma after spinal manipulation. Surg Neurol Int 2014;5:55

2 Andrews DW, Lavyne MH. Retrospective analysis of microsurgical and standard lumbar discectomy. Spine 1990;15(04):329-335

3 Brouwer PA, Brand R, van den Akker-van Marle ME, et al. Percutaneous laser disc decompression versus conventional microdiscectomy in sciatica: a randomized controlled trial. Spine J 2015;15(05):857-865

4 Bokov A, Isrelov A, Skorodumov A, Aleynik A, Simonov A, Mlyavykh $\mathrm{S}$. An analysis of reasons for failed back surgery syndrome and partial results after different types of surgical lumbar nerve root decompression. Pain Physician 2011;14(06):545-557

5 Fan G, Han R, Zhang H, He S, Chen Z. Worldwide research productivity in the field of minimally invasive spine surgery: a 20-year survey of publication activities. Spine 2017;42(22): $1717-1722$

6 Jasper GP, Francisco GM, Telfeian AE. Endoscopic transforaminal discectomy for an extruded lumbar disc herniation. Pain Physician 2013;16(01):E31-E35

7 Lühmann D, Burkhardt-Hammer T, Borowski C, Raspe H. Minimally invasive surgical procedures for the treatment of lumbar disc herniation. GMS Health Technol Assess 2005;1:Doc07

8 Xin G, Shi-Sheng H, Hai-Long Z. Morphometric analysis of the YESS and TESSYS techniques of percutaneous transforaminal endoscopic lumbar discectomy. Clin Anat 2013;26(06):728-734
9 Nellensteijn J, Ostelo R, Bartels R, Peul W, van Royen B, van Tulder $M$. Transforaminal endoscopic surgery for symptomatic lumbar disc herniations: a systematic review of the literature. Eur Spine J 2010;19(02):181-204

10 Jasper GP, Francisco GM, Telfeian AE. Clinical success of transforaminal endoscopic discectomy with foraminotomy: a retrospective evaluation. Clin Neurol Neurosurg 2013;115(10): 1961-1965

11 Gibson JNA, Subramanian AS, Scott CEH. A randomised controlled trial of transforaminal endoscopic discectomy vs microdiscectomy. Eur Spine J 2017;26(03):847-856

12 Pan Z, Ha Y, Yi S, Cao K. Efficacy of transforaminal endoscopic spine system (TESSYS) technique in treating lumbar disc herniation. Med Sci Monit 2016;22:530-539

13 Cong L, Zhu Y, Tu G. A meta-analysis of endoscopic discectomy versus open discectomy for symptomatic lumbar disk herniation. Eur Spine J 2016;25(01):134-143

14 Hsu HT, Chang SJ, Yang SS, Chai CL. Learning curve of fullendoscopic lumbar discectomy. Eur Spine J 2013;22(04):727-733

15 Macnab I. Negative disc exploration. An analysis of the causes of nerve-root involvement in sixty-eight patients. J Bone Joint Surg Am 1971;53(05):891-903

16 Fairbank JC, Pynsent PB. The Oswestry Disability Index. Spine 2000;25(22):2940-2952; discussion 2952

17 Price DD, McGrath PA, Rafii A, Buckingham B. The validation of visual analogue scales as ratio scale measures for chronic and experimental pain. Pain 1983;17(01):45-56

18 Turner-Bowker DM, Bayliss MS, Ware JE Jr, Kosinski M. Usefulness of the SF-8 Health Survey for comparing the impact of migraine and other conditions. Qual Life Res 2003;12(08):1003-1012

19 Ahn Y, Lee HY, Lee SH, Lee JH. Dural tears in percutaneous endoscopic lumbar discectomy. Eur Spine J 2011;20(01):58-64

20 Peul WC, van Houwelingen HC, van den Hout WB, et al; LeidenThe Hague Spine Intervention Prognostic Study Group. Surgery versus prolonged conservative treatment for sciatica. N Engl J Med 2007;356(22):2245-2256

21 Weinstein JN, Lurie JD, Tosteson TD, et al. Surgical versus nonoperative treatment for lumbar disc herniation: four-year results for the Spine Patient Outcomes Research Trial (SPORT). Spine 2008; 33(25):2789-2800

22 Strömqvist F, Strömqvist B, Jönsson B, Karlsson MK. The outcome of lumbar disc herniation surgery is worse in old adults than in young adults. Acta Orthop 2016;87(05):516-521

23 Liu X, Yuan S, Tian Y, et al. Comparison of percutaneous endoscopic transforaminal discectomy, microendoscopic discectomy, and microdiscectomy for symptomatic lumbar disc herniation: minimum 2-year follow-up results. J Neurosurg Spine 2018;28 (03):317-325

24 Wang Y, Luo G, Wang J, Zhu M, Li C, Teng H. Early postoperative magnetic resonance imaging findings after percutaneous endoscopic lumbar discectomy and their correlations with clinical outcomes. World Neurosurg 2018;111:e241-e249

25 Floris R, Spallone A, Aref TY, et al. Early postoperative MRI findings following surgery for herniated lumbar disc. Acta Neurochir (Wien) 1997;139(03):169-175

26 Annertz M, Jönsson B, Strömqvist B, Holtås S. Serial MRI in the early postoperative period after lumbar discectomy. Neuroradiology 1995;37(03):177-182

27 Martín-Láez R, Martínez-Agüeros JA, Suárez-Fernández D, Montiaga-Núñez F, Vázquez-Barquero A. Complications of endoscopic microdiscectomy using the EASYGO! system: is there any difference with conventional discectomy during the learning-curve period? Acta Neurochir (Wien) 2012;154(06):1023-1032

28 Joswig H, Richter H, Haile SR, Hildebrandt G, Fournier JY. Introducing interlaminar full-endoscopic lumbar diskectomy: a critical analysis of complications, recurrence rates, and outcome in view of two spinal surgeons' learning curves. J Neurol Surg A Cent Eur Neurosurg 2016;77(05):406-415 
29 Yörükoğlu AG, Göker B, Tahta A, et al. Fully endoscopic interlaminar and transforaminal lumbar discectomy: analysis of $47 \mathrm{com}-$ plications encountered in a series of 835 patients. Neurocirugia (Astur) 2017;28(05):235-241

30 Tenenbaum S, Arzi H, Herman A, et al. Percutaneous posterolateral transforaminal endoscopic discectomy: clinical outcome, complications, and learning curve evaluation. Surg Technol Int $2011 ; 21: 278-283$

31 Morgenstern R, Morgenstern C, Yeung AT. The learning curve in foraminal endoscopic discectomy: experience needed to achieve a 90\% success rate. SAS J 2007;1(03):100-107

32 Singh S, Sardhara JC, Khatri D, et al. Technical pearls and surgical outcome of early transitional period experience in minimally invasive lumbar discectomy: a prospective study. J Craniovertebr Junction Spine 2018;9(02):122-129

33 Sanusi T, Davis J, Nicassio N, Malik I. Endoscopic lumbar discectomy under local anesthesia may be an alternative to micro- discectomy: a single centre's experience using the far lateral approach. Clin Neurol Neurosurg 2015;139:324-327

34 Wilson DH, Harbaugh R. Lumbar discectomy: a comparative study of microsurgical and standard technique. In: Hardy RW, ed. Lumbar Disc Disease. New York, NY: Springer; 1982:147-156

35 Goald HJ. Microlumbar discectomy: follow-up of 477 patients. J Microsurg 1980;2(02):95-100

36 Yeung AT, Tsou PM. Posterolateral endoscopic excision for lumbar disc herniation: surgical technique, outcome, and complications in 307 consecutive cases. Spine 2002;27(07):722-731

37 Schaffer JL, Kambin P. Percutaneous posterolateral lumbar discectomy and decompression with a 6.9-millimeter cannula. Analysis of operative failures and complications. J Bone Joint Surg Am 1991;73(06):822-831

38 Lee DY, Lee SH. Learning curve for percutaneous endoscopic lumbar discectomy. Neurol Med Chir (Tokyo) 2008;48(09):383-388 ; discussion 388-389 